\title{
Niklas Luhmann's radical communication approach and its implications for research on organizational communication
}

\author{
Cooren, François ; Seidl, David
}

\begin{abstract}
In this review essay, we explore how Luhmann's radical communication approach, which conceptualizes communication without recourse to human beings' intentions, can reorient existing research on organizational communication. We show how Luhmann's perspective puts decisions back into organizational communication studies, how it changes our perspective on organizational continuity and on organizational boundaries, and how it redirects our understanding of human agency in organizations. We also discuss three areas in which Luhmann's theory could draw inspiration from other research on organizational communication. Keywords: autopoiesis, communication, Niklas Luhmann, organization studies, systems theory.
\end{abstract}

DOI: https://doi.org/10.5465/amr.2018.0176

Posted at the Zurich Open Repository and Archive, University of Zurich ZORA URL: https://doi.org/10.5167/uzh-174709

Journal Article

Accepted Version

Originally published at:

Cooren, François; Seidl, David (2020). Niklas Luhmann's radical communication approach and its implications for research on organizational communication. Academy of Management Review, 45(2):479497.

DOI: https://doi.org/10.5465/amr.2018.0176 
organizational communication

\author{
François Cooren
}

Université de Montréal

f.cooren@umontreal.ca

\title{
David Seidl
}

University of Zurich

david.seidl@uzh.ch

Paper accepted for publication in the Academy of Management Review

\begin{abstract}
In this review essay, we explore how Luhmann's radical communication approach, which conceptualizes communication without recourse to human beings' intentions, can reorient existing research on organizational communication. We show how Luhmann's perspective puts decisions back into organizational communication studies, how it changes our perspective on organizational continuity and on organizational boundaries, and how it redirects our understanding of human agency in organizations. We also discuss three areas in which Luhmann's theory could draw inspiration from other research on organizational communication. Keywords: autopoiesis, communication, Niklas Luhmann, organization studies, systems theory.
\end{abstract}

\section{Acknowledgements}

We would like to thank Jean Bartunek and the two anonymous reviewers for their great help in developing this manuscript. 


\title{
Niklas Luhmann's radical communication approach and its implications for research on organizational communication
}

\author{
François Cooren and David Seidl
}

\begin{abstract}
In this review essay, we explore how Luhmann's radical communication approach, which conceptualizes communication without recourse to human beings' intentions, can reorient existing research on organizational communication. We show how Luhmann's perspective puts decisions back into organizational communication studies, how it changes our perspective on organizational continuity and on organizational boundaries, and how it redirects our understanding of human agency in organizations. We also discuss three areas in which Luhmann's theory could draw inspiration from other research on organizational communication. Keywords: autopoiesis, communication, Niklas Luhmann, organization studies, systems theory.
\end{abstract}

\section{INTRODUCTION}

With his suggestion to conceptualize organizational communication without recourse to human beings' intention, the German sociologist Niklas Luhmann has offered a radically new perspective on communicational phenomena in organizations. Luhmann developed this new perspective across numerous publications culminating in a comprehensive theory of organizations as self-reproducing sytems of communications. These writings, particularly the magnum opus Organization and Decision (Luhmann, 2018), contain many fascinating new insights that have the potential to reorient existing research on organizational communication.

Yet, while Luhmann is considered one of the most influential organization theorists in the German-speaking world, his works have received only little recognition from organization scholars at the international level. Despite fragmented attempts at introducing Luhmann's approach to organization scholars internationally (Bakken and Hernes, 2003; Hernes and Bakken, 2003; Schoeneborn, 2011; Seidl and Becker, 2005, 2006; Czarniawska, 2017), and at mobilizing his ideas in examining specific aspects of organization studies such as 
boundaryless careers (Becker and Haunschild, 2003), organizational identity (Seidl 2005), the theory-practice gap (Kieser and Leiner, 2009), sustainability (Valentinov, 2012; 2013), organizational values (Schnebel, 2000), organizational technologies (van Lier, 2013), Luhmann remains, as of today, a relatively marginal figure in organization studies.

Apart from the complexity of his writing, a main reason for this neglect of his theory is the lack of translations of his main works on organization. Without such translations, the engagement with his organization theory had to remain on the superficial level of those few glimpses of his work that German-speaking authors have provided with their own interpretations of Luhmann's work, which 'do not give a full grasp of his achievements' (Thyssen, 2012: 117). Yet, with the recent translation into English of Luhmann's (2018) magnum opus on organizations, there is now the opportunity for a fuller and deeper engagement with his thinking in organization studies in general and organizational communication research in particular, as all researchers will be able to consult the original text.

We take this publication as an opportunity to discuss how Luhmann's approach can contribute to our understanding of the communicative dimension of organizations and thereby to the burgeoning literature on the communicative constitution of organizations (CCO), which proposes that organizations should essentially be considered the products of communicative activities (Ashcraft, Kuhn and Cooren, 2009; Cooren, 2000, 2015; Kuhn, Ashcraft and Cooren, 2017; McPhee and Zaug, 2000; Robichaud, Giroux and Taylor, 2004; Schoeneborn and Vásquez, 2017; Taylor and Van Every, 2000, 2011, 2014).

In the following we start by introducing Luhmann's take on organizations as selfreproducing communication systems. Yet, rather than summarizing his organization theory, which would be impossible within the scope of an article given the complexity of the work, we will distil what we consider his key insights and claims with regard to the communicative 
dimension of organizations. This is followed by a discussion of how these insights and claims can enrich and re-direct existing organizational communication scholarship. After that, we will also briefly reflect on possibilities of extending Luhmann's theory with insights from other communication theories. We conclude with some general reflections on how to use Luhmann's approach in the context of other existing communication approaches.

\section{KEY ASPECTS OF LUHMANN'S COMMUNICATION APPROACH TO ORGANIZATIONS}

Niklas Luhmann (1927-1998) was one of the most important German sociologists of the Twentieth century. Having started out as a lawyer and having worked in that function for several years, a scholarship to go to Harvard University inspired him to embark on an academic career in the social sciences. After various positions at several German universities, Luhmann ended up at the University of Bielefeld, where he developed his distinctive communication approach to the social world in general and to organizations in particular. In what follows, we will introduce the key aspects of Luhmann's theory of organization first before discussing its implications for organization communication research. Given the complexity of Luhmann's approach, it is necessary to grasp the overall architecture of the theory first in order to be able to appreciate its implications for organizational communication studies.

\section{Communications as basic elements of the social world}

Niklas Luhmann is often referred to as a theorist of society (Luhmann 2012), which was the key focus of his work. However, during his entire career, he took a great interest in organizations as well and developed a very distinctive organization theory. The most elaborate version of this organization theory is presented in his book Organization and Decision (Luhmann, 2018), which was originally published in German in 2000, two years after his death. Yet, his organization theory has to be seen in the wider context of his approach 
to the social world in general, which he outlined in a range of other books (e.g. Luhmann 1995; 2012a). Key to Luhmann's general approach to the social world is the conceptualization of the social domain as constituted exclusively of verbal and non-verbal communication. That is, Luhmann treats communication rather than individuals or action as the basic concept of social theory (Luhmann, 1995).

Drawing on Bühler's (1990/1934) classical communication theory, Luhmann conceptualizes communication as the unity of utterance, information and understanding: an utterance is understood as conveying a particular information. Yet, Luhmann adds an important twist to this classical conceptualization. Instead of focussing on how the involved human beings interiorly understand the utterance, he directs the attention to the understanding that is displayed in the response to the focal communication. Given that nobody has any direct access to how a person interiorly understands an utterance (except, of course, that person herself), in the communicational world, understanding is only something that can be assessed on the way it is displayed by the next turn of talk, a position that is perfectly congruent with one of the main tenets of conversation analysis (Schegloff, 1991).

To illustrate this point, let's take the following sequence of communications between a customer and a salesperson: "I don't need a receipt" - "Sorry, but I have to charge VAT." Implied in the response to the first communication is an understanding of the customer's utterance as a suggestion to keep the sales transaction off record in order not to pay any taxes on it. This is a very different understanding than if the response had been "Great, then we don't have to waste any paper," which implies an understanding of the first utterance as just referring to the physical object (even though we would have to wait for the response to the response to establish how the response is understood in turn). Here, we focus just on the understanding as materialized in the responses, leaving aside what the involved human beings might be thinking during this conversation (the salesperson might think that the customer is 
suggesting to keep the transaction off record but for whatever reason still say, "Great, then we don't have to waste any paper"). For all practical purposes, what people might be thinking or understanding can certainly be of import to the interlocutors themselves, but as long as the latter do not materialize in the discussion, whether implicitly or explicitly, these matters are not talked into being (Heritage, 1984), which means that, from a communicational point of view, they do not exist.

This seemingly small twist that consists of focussing on the understanding displayed in the response rather than on the understanding in the human beings' minds has far reaching, theoretical consequences. Since the response communication determines how the initial communication is understood, the person making the utterance has no control over the communication. Instead, it is the responding communication that determines the focal communication by displaying a particular understanding. Yet, as the response communication itself is only determined by the response to the response communication, the person uttering the response has no control over the communication either. Instead, the communications around the focal communications determine the focal communication through the understanding displayed in them. Luhmann, in this sense, speaks of communication as an autonomous realm of reality, which is not determined by the intentions or thoughts of human beings.

To underline this point, Luhmann (2002: 169) provocatively stated: 'Humans cannot communicate; not even their brains can communicate; not even their conscious minds can communicate. Only communications can communicate." This is obviously an overstatement as we constantly witness situations where people appear to communicative seamlessly. For instance, if $\mathrm{X}$ asks $\mathrm{Y}$ to pass her a file and that $\mathrm{Y}$ extends it to her, a gesture to which $\mathrm{X}$ responds by thanking him, one can reasonably say that $\mathrm{X}$ and $\mathrm{Y}$ communicated successfully. However, what Luhmann means is that we do not need to know what is in X's and Y's minds 
to precisely conclude that communication took place and succeeded. The mutual understanding is displayed in the communications themselves, which is all that matters from a social viewpoint. We therefore no longer need to ask "who is saying something?" as everything is said in and by the communications.

This also means that individual units of communication can only come about as part of a sequence of communications, or as Luhmann would say: a system of communications. The most general form of such a system of communications is our society (Luhmann, 2012b, 2013). Society encompasses all communications and "everything that is communication is society" (Luhmann 1995: 408). In other words, communications constitute the building blocks by which society get reproduced and transformed, which explains why what is in people's mind does not ultimately matter, socially and organizationally speaking.

In line with this general understanding of the social world as constituted by an autonomous realm of communications rather than individuals or actions, Luhmann developed his theory of organizations as particular communicative phenomena, made up of particular types of communication, within society. As we will discuss in more detail below, this conceptualization of the social world as made up exclusively of communications has farreaching consequences as it forces the organization researcher to trace all organizational phenomena, whether organizational boundaries or managerial agency, back to communications and their dynamics. It also means that we have to distinguish clearly between the social world as the world of communication and the worlds of the individuals as worlds made up of thoughts in their respective minds, which might trigger communications but as thought can never become part of the social world as such.

\section{Capturing how organizations distinguish themselves from the rest of society}

Having conceptualized society as the all-encompassing system of communication (i.e., all communications are part of our world-spanning society), Luhmann treats organizations as 
particular systems within that realm of communication. These systems are distinguished from the rest of society by the fact that they are made up of a particular type of communications, i.e. of particular units of utterance, information and understanding. Luhmann refers to this type of communications as decision communications (or simply: "decisions", since Luhmann does not distinguish between decisions and decision communications as we will explain below). While we might find decision communications also outside of organizations, for Luhmann organizations are the only systems that consist entirely of decision communications.

Luhmann defines decision communications as a kind of complex communication; a decision communication contains information about a particular content (e.g., "We will invest in machine X...”) but at the same time it also contains information about alternatives to that content (e.g. “... and we won't invest in machine Z” or “... instead of continuing to produce on the existing machine") or at least the fact that there are alternatives. It also contains information, at least implicitly, about "its reasons, its justification, the effort involved" (Luhmann, 2018: 148). Because of the different aspects that are combined in a decision communication, Luhmann speaks of decision communications as particular types of "compact communications" (Luhmann, 2018: 148). Often the different aspects of a single decision are realized as several "normal" communications (each consisting of utterance, information and understanding) which are bundled together into a decision communication.

It is this particular type of communication that distinguishes the organization from the rest of society. Taking this line of argument even a step further, Luhmann suggests that with this characterization of the organization, he as researcher is not just imposing this distinction between different types of communications onto the world but organizations themselves use this distinction to identify themselves. That is, organizations themselves, as Luhmann claims, refer (explicitly or implicitly) to their decision communications whenever they refer to themselves, e.g. they refer to the mission statement that was decided on. And every decision 
communication also distinguishes between the decision communications that it can treat as part of the same organization, and thus can use as basis for justifying itself as particular decision, and other communications that are not considered part of the same organization.

To stress the point that organizations consist just of interconnected decision communications and nothing else (in particular, not of individuals), Luhmann appropriates the biological concept of autopoietic systems (Maturana and Varela 1992), i.e. self-reproducing systems, which was originally put forward by the Chilean biologists Humberto Maturana and Francisco Varela (1992), and re-interprets it as a sociological concept (Seidl, 2005). Autopoietic systems, as Luhmann describes them, are systems that are not just distinguished analytically by the researcher but are systems that actively generate a distinction between themselves and their environment. Luhmann explains: "If we describe organizations as autopoietic systems, we are [...] concerned with the generation and reproduction of a difference (systems-theoretically: between system and environment), and the concept of autopoiesis means that an observer who uses it presupposes that this difference is generated by the system itself and reproduced by systemic operations" (Luhmann, 2018: 35; italics in original).

Together, this leads Luhmann to define organizations as autopietic systems that are "made up of decisions, and capable of completing the decisions that make them up, through the decisions that make them up" (Luhmann, 2003: 32). Nassehi (2005: 185) in this sense also speaks of organizations as "decision machines," that is, as a network of interconnected decisions that produces further decisions. Hence, whatever decisions are interconnected in that way we can speak of an organization. This also means that all decisions that are connected in that way belong to that organization and those that are not connected in that way belong either to other organizations or are "free-floating" decisions in society at large. 
This conceptualization of organizations as demarcating themselves from the environment through their decision communications also means that every new decision communication that is produced reproduces the demarcation between the organization and its environment. Interestingly, this means that we can no longer speak of a boundary that demarcates what is inside and what is outside the organization. Instead, it is the system of interconnected decision communications that, for each communication, determines whether it is treated as part of the organization or not, i.e. whether it should be understood as a decision communication of that particular organization or not. Also empirically we can observe decision communications that deliberate what communications can be treated as decisions and which ones not. This forces the organizational communication researcher to pay much more attention to the ways in which the organizational communications determine which communications to treat as part of the organization and which ones not, as we will discuss in more detail below.

\section{The paradox of decision at the heart of the organization}

In elaborating on his concept of organizations as systems made up of decisions. Luhmann (2018: 2005) draws on some central concepts from classical organization theory and "reformulates" them on the basis of his particular communication perspective (Luhmann, 2018: 51). The first concept reformulated in this way is the very concept of decision itself. While classical organization theory distinguishes between taking a decision and communicating the decision, Luhmann collapses the distinction, treating decisions as forms of communication. As he writes: "Decision is not understood as a psychological mechanism, but as a matter of communication, not a psychological event in the form of an internally conscious definition of the self, but as a social event. That makes it impossible to state that decisions already taken still have to be communicated.” (Luhmann 2003: 32). 
Accordingly, the classical notion of decision as process of choosing one amongst several alternatives (March, 1994) is re-described as communicating the selection of one alternative amongst other possible alternatives. This results in paradoxical communications, as Luhmann (2018: 111) highlights:

The decision has to inform about itself, but also about the alternative, thus about the paradox that the alternative is an alternative (for otherwise the decision would not be a decision) and at the same time not an alternative (for otherwise the decision would not be a decision).

Hence, other than the decision-making literature or even the literature on organizational communication has acknowledged, decision communications are self-contradictory communications. On the one hand, decision communications communicate that there are real alternatives to the selected alternative and hence, that the other alternatives could have been chosen equally well - otherwise there is nothing to decide. On the other hand, decision communications communicate that the selected alternative is the right alternative to select and that the other alternatives are not "real" alternatives - otherwise the selected alternative would not be accepted as already decided. Hence, decision communications have to communicate both that there are and are not alternatives.

This paradoxical form makes decisions, on the one hand, very fragile, in the sense of being constantly at risk of being deconstructed, i.e. of being questioned, but on the other hand, it provides them with a power, which Luhmann, drawing on another classical concept (March \& Simon, 1958) referred to as "uncertainty absorption": Decisions, to the extent that they are not questioned but taken as basis for further decision making, provide ensuing decisions with stable points of reference, i.e., with selected alternatives; for the ensuing decisions the uncertainties involved in the original decision do not matter anymore - the decision has 
already been taken (whether it was a good or bad decision is irrelevant for the ensuing decision).

As Luhmann writes: "Uncertainty absorption takes place, [...] when decisions are [...] taken as the basis for subsequent decisions" (Luhmann 2005b: 96). Hence, compared to the succession of "normal" communications, the information processing by decisions turns uncertainties into certainties. This capacity of decisions to absorb uncertainty also results in a particular capacity to establish organizational structures. Drawing on another classical concept (March and Simon, 1958), Luhmann refers to these structures as "decision premises." He defines decision premises as explicit decisions about a range of other decisions. For example, organizations, that is, the network of decisions, produce decisions on decision programs such as strategies or policies that provide stable points of reference for future decision making.

In order to reduce the risk of decisions being deconstructed, i.e. questioned by ensuing decisions, and the organization to collapse, organizations have established forms of “deparadoxification,” i.e., of hiding the paradox of decisions (Seidl and Becker, 2006 Knudsen, 2005). The first form of deparadoxification is the reference of decisions to decision premises; thereby the focal decisions appear as "derived" from and legitimated through decision premises. For example, the decision to acquire a new company may be communicated as a direct consequence of the decision premise to grow the business through acquisitions. This reference to decision premises shifts the attention away from the focal decisions to the decision premise. The second form of deparadoxification is the construction of the "operational fiction" (Luhmann, 2018: 67) of a decision maker. That is, in the decision communications the decisions are typically attributed to decision makers, as if the decisions were produced by the decision makers rather than by the network of decisions. As a result, the focus of ensuing decision communications are shifted from the focal decisions to the motives of the decision makers and thereby out of the communication. 
The risk of deconstruction, i.e. the risk of exposing the paradox at the heart of the decision, is further reduced through the fact that decisions are totalized in organizations as the only form of organizational communication. As explained above, organizations consist only of decisions and hence the deconstruction of decisions can also just take place in the form of decisions, which as a consequence would result in further decisions and thus continue the reproduction of the organization. To be sure, there are also other communications "around" the decision processes, e. g. gossip, but those communications are not part of the recursive network of decisions and hence not part of the organization as conceptualized by Luhmann.

As we will discuss in more detail below, Luhmann's conceptualization of organizations as constituted of decision communications, on the one hand, brings decisions (back) into organization communication studies. As Luhmann's analysis highlights, decision communications are a distinctive form of communication, which poses challenges and yield different consequences than the communications typically studied by organizational communication scholars. On the other hand, this conceptualization connects organizational communication research back to the classical organization theory of the Carnegie School, allowing to build on the insights of this important stream of research. Yet, rather than reintroducing the existing concepts from classical organization theory, Luhmann re-interprets the concepts from his communication perspective giving them a new meaning and thereby new analytical power.

\section{Information processing through decision communications}

By describing organizations as constituted by decision communications and nothing else, Luhmann develops a radically temporal perspective on organizations. Decision communications, like all communications, are "events occurring at a fixed point in time and then disappear" (Luhmann, 2003: 35); i. e. the decision communication just happens at a particular moment and does not extend beyond that. This is not to deny that decisions can 
have long-lasting effects but the decisions as events do not persist over time. This means that in order for an organization to persist over time, the network of decisions has to ensure that its decisions are followed by further decisions; once the succession of decisions stops, the organization disappears.

Hence, in line with process theorists in management studies (e.g. Tsoukas and Chia, 2002; Langley et al. 2013; Langley and Tsoukas, 2016), Luhmann suggests a reversal of the traditional perspective on continuity and discontinuity - where organizations are considered to be in constant flux and stability or persistence are the phenomena in need of explanation. Yet, as Luhmann explains, this focus on decision events also goes beyond the existing process theorizing ; in fact, in some sense it is even in opposition to it: While processes, as described by Langley and Tsoukas (2016) and others, extend across time and thus have (at least) some temporal continuity, events happen as points in time and have no continuity whatsoever. Luhmann writes:

"[T]he theory presumes discontinuity, continuous disintegration, and considers continuity (thingness, substance, process) to need explaining. A theory [...] construed in this manner is in radical opposition to all sorts of process theories, including dialectical theories. It rejects any sort of 'essentialism' and, on the contrary, demands that every event (or in our field every decision) leave the following one to a subsequent event.” (Luhmann, 2018: 30).

For the continuation of the organization, it only matters that decisions are continuously produced but not what particular decisions are produced, as long as the decisions possess "connectivity" (Luhmann, 2018: 36). The concept of "connectivity" refers to the ability of decisions to connect to other decisions; that is, decisions need to possess connectivity so that new decisions can connect to them and thereby ensure the continuation of the organization. Like all communications, decisions typically call forth ensuing decisions. 
For example, the decision to create a new position in the organization calls forth an ensuing decision on hiring a person to fill the position. Once this person has been selected, she will then be positioned as having to make subsequent decisions in connection with her new responsibility, and so on and so forth.

Luhmann suggests that we conceptualize this process of decisions connecting to ensuing decisions as information processing and the entire organization as an information processing system. Drawing on Bateson's (1979: 250) definition of information as "any difference that makes a difference," Luhmann argues that decisions serve as information (that has been uttered and which needs to be understood as well) to ensuing decisions: they are differences that make a difference in the decisions that follow. However, what difference a decision makes in ensuing decisions is only determined by the ensuing decision itself; that is, the ensuing decision reads a particular difference into the preceding decision, which it takes as point of reference for itself as a decision. In this sense we can also say that it is ensuing decisions that determine retrospectively the meaning of the earlier decisions and whether they are to be treated as decisions at all - if a decision does not make a difference in later decisions it is not a decision.

Taking this a step further, Luhmann argues that all information that is processed within the succession of decisions is generated by the organization itself, i.e., by the network of decisions. In the same way as decisions read particular differences into preceding decisions, they also read particular differences into the environment, where the environment is constituted of everything that is not part of the organizational network of decisions. Those differences that the decisions read into the environment are then used as occasions for further decision making. For example, organizations might read a change in customer behavior into the environment requiring a decision to change the marketing campaign. Thus, the information that the organization extracts from its environment is not just existing out there 
to be picked up but is constructed by the organization itself. In other words, what environmental differences make a difference to the decision-making process depends on the decision-making process.

Luhmann in this sense writes:

The concept of difference replaces the concept of fact, which is no longer needed thanks to the assumption that systems react only to differences that they make themselves, which therefore do not need to exist 'out there' but have to be constructed 'inside' (Bateson incidentally understands facts as the infinity of possible differences to which systems can react only by determining what differences make a difference for it in deciding its own states). (Luhmann, 2018: 37)

This notion of organizations as information-processing systems leads to the concept of "operational closure," where operational closure means "that the system can operate only in the context of its own operations" (Luhmann 2018: 33), yet, as we will elaborate this does not imply a classical closed system view according to which the environment would be irrelevant.

Since information is always relative to the system, that is, since the difference that a difference makes in the information-processing system, i.e. in the organization, is constructed by the operations of the system itself, all operations of information processing are by definition part of the information-processing system itself - no information processing operations can be introduced from outside. In this sense, Luhmann writes: "All operations of the system are information processing. We thus merely repeat that [organizations] are operationally closed systems" (Luhmann, 2018: 37; italics in the original). This operative closure also applies to the relation between the organization and human beings. Not even human beings can introduce information into the communication system, although communication presupposes the participation of human beings. 
Luhmann captures this relation between the communication system and the human beings with the concept of interpenetration. By that he means that the communication system makes use of the complex operations of the mind as if those operations were part of the communication system (Luhmann 1995: 2013). This is analogous to what we do when using a computer to calculate something - we do not need to understand what is going on in the computer, and the operations of the computer do not become operations of our mind, but we can still make use of the results the computer displays on the screen (e.g., the calculation the computer produces on the screen counts as what we calculated). In the same way, as Luhmann writes, the organization has human beings "at its disposal" (Luhmann, 2018: 32) to provide "irritations" that the organization can make use of in producing communications. For example, when a question is communicated, the communication system can rely on the addressed human being to react by creating a sound or a gesture that can be "used" as basis for reading a response communication into it, independently of what the human being "really" thought or intended.

Luhmann stresses that this strict separation between the organization's own information processing and that of other systems in its environment enables the organization to produce information at all. This leads to the seemingly paradoxical conclusion that operational closure, i.e., the fact that all operations of information processing are produced by the system itself and cannot be introduced from outside, is the precondition for being open to processing information about the internal and external world.

This conceptualization of organizations as operatively closed communication systems, has important consequences for theorizing the relation between the organization and its environment. This means that the impact of operations outside the organization, such as the communications of other organizations or the thoughts of their organizational members, is determined by the focal organization's communication processes. As Luhmann stresses, these external operations can merely cause "irritations" (Luhmann 2018: 55) in the communication process which might trigger 
further communications, but what communications they might trigger is determined by the communication process and not the irritation. In other words, external operations can never enter the organization as such but the organization can read particular differences into them, which it then uses as occasions for further communications. Thus, what internal communications are triggered by external operations and whether any internal communications are triggered at all, depends entirely on the internal organizational communication processes themselves. This has also important consequences for theorizing the agency of organizational members: The organizational members can only impact the organizational communications to the extent and in the way that the organizational communications allow for. As we will discuss below, this means that the agency of the organizational members has to be treated as communicatively constructed.

\section{HOW LUHMANN CAN INSPIRE STUDIES ON THE COMMUNICATIVE DIMENSION OF ORGANIZATION}

As we have shown above, Luhmann offers a radical communication perspective on organizations, which conceptualizes organizations and the communications of which they are made up without recourse to human beings' intentions. In the following, we will elaborate on how Luhmann's perspective relates to and can inspire existing research on organizational communication. We will argue that even if we do not follow all of Luhmann's suggestions, in particular, even if we do not follow his suggestion of conceptualizing organization as consisting of decision communications only, he can offer important inspirations to organizational communication scholarship.

In particular, we discuss how Luhmann's perspective (1) puts decisions back into organizational communication studies, how it changes our perspective (2) on organizational continuity and (3) on organizational boundaries, and (4) how it redirects our understanding of human agency in organizations. For each of these four areas we highlight exemplary contemporary themes in organizational communication research to which Luhmann has something specific to say, including recent research on strategy as discourse, the 
communicative constitution of organizational identity, the polyphonic nature of organizations and leadership as communicatively enacted.

\section{Putting decisions back into organizational communication research}

As explained, one of the key points Luhmann insists on throughout his work is that anything that participates in the re-production of an organization has to be treated as the result of a decision communication. Whether these results consist of a specific function, procedure, plan, etc., its instantiation has to be decided upon at some point. While the existing literature on the communicative constitution of organizations highlight that organizations are made of communications (Cooren, 2000; McPhee and Zaug, 2000; Taylor, Cooren, Giroux and Robichaud, 1996; Taylor and Van Every, 2000), Luhmann's work draws our attention to the differences between different types of organizational communication. In particular, it highlights that decision communications play a distinctive role in that constuitution and that we should acknowledge that role.

While also relevant to organizational communication studies in general, Luhmann's detailed analysis of the particularities of decision communications speaks directly to the recent discussions about the communicative constitution of strategy-making (Aten and Thomas, 2016; Bencherki, Basque and Rouleau, in press; Cabantous, Gond and Wright, 2018; Cooren. Bencherki, Chaput, and Vásquez, 2015; Pälli, 2018; Vásquez, Bencherki, Cooren, and Sergi, 2018). This research is directly concerned with processes of strategic decision making, examining the way in which they are communicatively constituted. Yet, the respective research has hardly paid any attention to the decision communication as a particular type of communication. Taking Luhmann seriously, even if one doesn't want to adopt his theoretical approach in its entirety, means treating such decision processes not only as empirical context for studying organizational communications but to pay particular attention to decision communication as pivotal communicative events in the unfolding 
communication process. After all, as Luhmann revealed, decision communications affect the dynamics of the communication in very distinctive ways.

Indeed, decisions create stable points of reference within the organizational communication; the communication can rely on what has been decided, that is, what has been instantiated and established so far. In other words, decisions are the ways by which organizations organize themselves, so to speak. Taking Luhmann's approach we can understand organizations as literally made of decisions to the extent that the result of these decisions constitutes what it ends up being made of and how it evolves throughout space and time, whether we speak about successive versions of organizational charts that defined how it was officially structured, strategic plans that consecutively determined where resources would be focused on, or even buildings that were progressively erected, bought or sold in its name. In other words, decisions communicate into being what constitute organizations.

Even if we do not follow Luhmann in conceptualizing organizations as consisting of decision communications only, we can read Luhmann's work as an invitation to organizational communication scholars to pay more attention to the particularities of decision communications in the constitution of organizations, not only because they absorb uncertainty, but also because of their paradoxicality. Analyzing the details of communication episodes, which is one of the trademarks of a communicative perspective on organization, would then consist of singularizing these specific moments where a collective course of action appears to be agreed upon to the detriment of others. Interestingly, one could then show how what we have referred to as the "game of authority" (Fauré, Cooren and Matte, 2019), which is usually implied in this kind of situation, can also be seen as another form of deparadoxification, i. e. of hiding the paradox, of the decision-making process.

By games of authority, we mean interactions where the authors/sources/origins/ premises of decisions are multiplied, which tends to obscure the paradoxicality of the 
decisions that are being made, rendering them less deconstructible. Deparadoxifying the decision-making process in this way thus could be described as consisting of multiplying the elements of a situation that are presented as dictating that a particular course of action be followed (Cooren, 2010). For instance, presenting a decision as being taken in the name of profitability, equity and environmental protection amounts to presenting these three matters as dictating that such a decision be made. Deparadoxification thus takes place as decisions appear to derive not from the decision itself, but from what leads to this decision. Showing within the decision communication that many elements of a situation call for a specific course of action indeed amounts to demonstrating that there is, in fact, no alternative while, by definition, the very existence of a decision does imply, as Luhmann reminds us, the existence of alternatives.

Beyond a focus on explicit decision communications, adopting a Luhmannian perspective invites us also to pay attention to the fact that even communications that are not explicitly framed as decisions might be treated as decisions by later decision communications. For example, communicating that one is leaving the office earlier today might be treated in later employee appraisal decisions as a decision to ignore the decisions on official working hours. This uncertainty about whether something will be treated as a decision communication or just as ordinary communication belonging to the environment is likely to affect both the decision communications and the "normal" communications around the organization.

Accordingly, we might start to examine the different ways in which the communication processes (both the decision communications and other communications around it) deal with this uncertainty of how they will be understood. Looking more closely at organizational communication processes, we often find, on the one hand, that some communications are explicitly flagged as decisions, e.g. "we have now decided...", in order to 
increase the chance that ensuing decision communications will treat them as such. We might think of meeting minutes which explicitly highlight that particular decisions have been taken.

While this increases the chance that these communications will be treated as decisions it is still no guarantee. After all, these communications could just be ignored by later decision communications. Interestingly, we often find explicit attempts at deconstructing such decision communications in order to prevent them from having any impacting on the other decision communications. For example, we can often observe how particular decision communications are accused of being in "breach of procedure", i. e. in conflict with earlier decisions, and hence should not be treated as decisions (and since decisions are only decisions to the extent that they are treated as such by later decisions, those decisions wouldn't be decisions).

On the other hand, we also find that communications around the organization might be explicitly flagged as non-decisions so that they may not be treated as decisions by the organizational decision process. For example, people might present some suggestions for a potential decision but highlight that these are to be interpreted just as initial thoughts and not as decisions - and hence not part of the organization. Often, we can also observe how particular communications during a business meeting are explicitly kept "off record" and hence off the official meeting minutes in order to prevent the interpretation of those communications as decisions - and thus as part of the organization. Yet, there is never a guarantee that such communications will not be interpreted as such and thereby become part of the organization.

Even the communication about keeping communications "off record" might be interpreted as decisions by later decision communications, possibly resulting in decisions about penalties. Taken together, organizational communication research might gain a better understanding of the dynamics of communication by paying more attention to how the difference between decision and non-decisions is handled communicatively. In our own work 
(Cooren, 2004, 2015), for example, we have shown how texts, i.e. written or otherwise recorded communication, play a key constitutive role in organizational settings, but Luhmann could help us show how these texts have such a constitutive role because they serve as ways by which decisions are officialised and thereby treated as such (see also Brummans, 2007; Taylor and Van Every, 2000, 2014).

\section{Focussing attention on the production of organizational continuities by discontinuities}

As we pointed out, a key issue in Luhmann's treatment of organizations, and social systems in general, is their fragile nature. Organizations are made up of communicative events that have no temporal continuity; they happen just as points in time. Hence, organizations only persist over time to the extent that communications are followed by further communications. After each communication the organization could break down and discontinue if no communication is to follow.

Taking this seriously means that organizational communication researchers might want to pay more attention to the ways in which an organizational communication process ensures the continuous production of further communications, an aspect that tends to be downplayed in current studies on organizational communication, which often cruelly suffer from a lack of concerns for longitudinality (Fairhurst and Cooren, 2018). Adopting a Luhmannian perspective we might re-interpret many mundane organizational processes as constituting occasions for the production of further decision communications and thus for the continuation of the organization. For example, the communication of a new strategy creates opportunities for decisions about implementing the strategy or the ambiguity of decision communications might themselves create occasions for further decision communications about the interpretation of those decisions.

Apart from the mere continuation of the reproduction of communications, the conceptualization of organizations as consisting of communicative events also directs our 
attention to the question of organizational identity, which is an important theme in the organizational communication literature (Albu and Etter, 2016; Bencherki and Snack, 2016; Bruscella and Bisel, 2018; Dobusch and Schoeneborn, 2015; Frandsen, Kuhn, and Wolff Lundholt, 2016; Koschmann, 2013; Schoeneborn, Kuhn, and Kärreman, 2019; Wilhoit and Kisselburgh, 2015). While the existing literature focusses particularly on the construction of organizational identity through "identity claims" (Dobusch and Schoeneborn, 2015) and "authoritative texts" (Koschmann, 2013; Kuhn, 2008), which are communicative accounts about the enduring characteristics of the organization, the Luhmannian perspective also directs attention to the way recognizable characteristics are generated in the ongoing flow of communications.

From a Luhmannian perspective, such continuity can be explained as the result of earlier communications affecting later communications; in other words, earlier communications are "present" in later communications in terms of the difference that they make to them. This is a form of continuity made of discontinuities. Hence, to better understand how this continuity is generated, organizational communication researchers might want to follow up on and examine closely this successive 'impregnation' (Luhmann 2018: 127) of decisions communications through earlier decision communications; that is, they may want to examine how earlier decisions express themselves in later decisions through the difference that they make in them.

This also has implications for theorizing organizational memory, i.e. remembering and forgetting, which is also becoming an important theme in organizational communication studies (Koschmann and McDonald, 2015; Langenmayr, 2016; Vasquez, Bencherki, Cooren, and Sergi, 2018). In the existing research on organizational communication, particularly as based on Taylor and Van Every's (2000, 2011, 2014) work, texts, i.e. written or otherwise recorded communication, would be treated as sources of organizational memory, as these 
texts preserve communications over time. With Luhmann, however, we might go a step further by acknowledging that what and how something is remembered in the organizational communication changes from communicative event to communicative event, as the meaning of these earlier communications are likely to change in that they make different differences in different ensuing communicative events. Apart from that, we would also have to acknowledge that beyond such texts, the organizational memory also manifests itself in the continuous impregnation of decisions through earlier decisions, as we described above.

Thus, for organizational communication scholars interested in understanding the workings of the organizational memory it is not enough to examine organizational texts but they will have to follow and examine the ongoing flow of communications. They will have to capture the ongoing impregnation and re-impregnation of communications through earlier communications. In other words, they will have to longitudinally observe what these texts concretely become in further communications. This will not only reveal how the past is reflected in the present communications but also how it is forgotten, that is, how it is made not to make a difference anymore. On that basis, we might also look into how in each individual moment of communication it is determined what earlier communications are allowed to make or not to make a difference.

\section{Exploring the self-referential production of organizational boundaries}

As indicated above, Luhmann's approach has important implications for the treatment of organizational boundaries, which differs from the existing conceptualizations in the communication literature. The Luhmannian perspective on boundaries indeed pushes us to explore how the organization recognizes whether a communication belongs to the organization or not. Every communication has to determine what other communications it can connect to as part of the same organization; for example, should earlier communications be treated just as gossip or as decisions and hence as part of the organization. In other words, the 
organization has to determine whether earlier decision communications can be treated as decision communications and hence as basis for the present decision communication, or whether they should rather be ignored as gossip.

For organizational communication scholars who want to follow Luhmann's approach, this means that we should explore in more detail the mechanisms through which at each moment in time the organization determines whether something is deemed a decision or not. This includes questions about the right to speak on behalf of the organization, i.e. the right to communicate decisions, but it is likely to include also other aspects such as the extent to which the earlier communication itself referred to yet earlier communications and thereby embedded itself in the network of decision communications.

And even for organization scholars who do not want to follow Luhmann in conceptualizing organizations as consisting of decisions only, there are important insights that can be drawn from his approach. Organizational communication researchers so far have typically addressed the question of boundaries in terms of the voices that are allowed to talk in the name of the organization (typically the ones of CEOs or official spokespersons, but also, in some contexts, the ones of salespersons or representatives) and thereby also define what the organization does and says (Cooren, Brummans and Charrieras, 2008; McPhee and Iverson, 2009; McPhee and Zaug, 2000; Smith and Ward, 2015). In this way, these voices also delimit what belongs and does not belong to the organization, that is, it is these voices that are supposed to define for the organization what it communicates.

While initially this right to speak on behalf of the organization was implicitly associated with a kind of membership of the organization, newer studies (Christensen, Morsing and Thyssen, 2011, 2013; Cooren, in press; Schoeneborn and Trittin, 2013; Trittin and Schoeneborn, 2017) have highlighted the "polyphonic nature" of organizational communications, i.e. the fact that "several voices are combined into a complex concept in 
which the individual voices can remain independent identities instead of being integrated into one monophonic voice or instead of being dominated by another homophonic voice" (Castélo et al. 2013: 688). As pointed out, there is a wide range of voices that can speak about the organization which goes beyond the ones of the organizational members (top and middle managers, spokespersons, employees) and includes other stakeholders (clients, suppliers, citizens, activists, politicians, journalists, etc.). Thus, in the recent debate on the polyphonic nature of organizational communications the notion of boundaries has become less clear-cut than it originally was.

Against this background, Luhmannian's perspective provides an important imput to this recent debate in drawing attention to the fact that there is an important asymmetry in this polyphonic game: only some of the voices are treated as authorized to speak on its behalf. With Luhmann, we would have to trace back this authorization to the communication process, and particularly to the decision process, itself. Although, as various communication scholars (Cooren, in press; Schoeneborn and Trittin, 2013; Trittin and Schoeneborn, 2017) have recently argued, many voices can talk about what the organization says or does (a talking about that can have important effects on its reputation and therefore on its image and constitution), with Luhmann we have to acknowledge that only authorized voices, e.g. of persons who have been appointed through the organizational decisions as representatives of the organization, can really communicate in the name or on behalf of or for the organization.

In other words, making an organization speak is, of course, not a free-for-all. This means that the polyphonicity of an organization could often be better compared to a concert where some are lead vocalists and take the central stage (the official spokespersons), while others are reduced to the role of backup singers (i.e., other employees, if they are allowed to sing!) or members of the crowd attending the concert (i.e., stakeholders). Although an organization constitutively is, to a certain extent, at the mercy of what is generally said about 
it, i.e., its reputation, Luhmann would point out that the organization also has the advantage, in normal circumstances, of deciding what voice are allowed to speak on its behalf, hence distinguishing itself from its environment and what it can say about it. Taking this perspective, thus, pushes organizational communication scholars, and particularly those with an interest in the polyphony of organizational voices, to explore how an organization can decide what is said in its name and thereby what it is made to say.

Such an exploration of how organizations decide who speaks in its name would have to go beyond an examination of how membership is communicatively constituted. After all, organizational members are not generally authorized to speak on behalf of the organization. Instead, the rights to speak on behalf of the organization are typically delimited according to topics and situations. For example, a salesperson might speak on behalf of the organization with regard to a particular sales situation but might not be authorized to do so in some other contexts. Hence, as researchers we would have to examine how those rights to speak are communicatively decided across people, contexts and topics.

\section{Exploring agency as a communicative phenomenon}

Luhmann's conceptualization of organizations as self-reproducing systems of communications urges communication scholars to trace all organizational operations back to communications. Taking this seriously means that we have to treat even what other communication theories refer to as human agency as a communicative phenomenon. This has important implications for organizational communication scholarship. While the existing literature has already partly acknowledged the communicative underpinnings of human agency (Cooren 2000; 2010, 2015), Luhmann's approach takes this a decisive step further.

Treating human agency as communicative phenomenon does not make human beings irrelevant (as highlighted above, organizational communication could not happen without human beings), but their agency has to be conceived of as determined by the network of 
communications. In other words, whether and, if so, what difference people make to what happens in communication has to be understood as determined by the network of organizational communications in which they participate. For the organizational communication researcher, this implies a reversal of the traditional approach to examining communications. Rather than starting from the individuals as source or origin of communications, the researcher has to start with the ongoing flow of communications and examine in what way it opens itself up to "irritations" from individual human beings, which it then uses as material for constructing further communications.

Above we explained the relation between the organization and human beings with the analogy of how we make use of the results of the complex operations of the computer for our own purposes, even though we do not understand the internal workings of the computer nor the computer understands how we think. We just open ourselves up to "irritations" from the computer and turn them into differences that make a difference in our thinking. Thus, even though less predictable than a computer, the organization can open itself up to human beings to produce irritations that are then used as basis for producing communications. For the organizational communication researcher this raises the important empirical question about how organizations determine where and how they open themselves up to these irritations from human beings.

To take again the computer analogy, as human beings we typically open ourselves up to what appears on the computer screen but not to the flow of electricity in the cables, and we only open ourselves up to some content on the screen ignoring others. Analogously, organizations open themselves up to be "irritated" by some operations by some human beings and not to others. In other words, we might trace the internal communication processes that determine where and how the communication processes open themselves up to particular irritations from particular human beings. In this regard we might look at decisions about 
memberships or decisions about forms of participation as those decisions are ultimately about what irritations are likely to be used as basis for the production of further decisions.

This general line of argument about human agency has also implications for the recent debate on leadership in the organizational communication literature (Clifton, 2015, 2017; Holm and Fairhurst, 2018, Larsson, 2017; Larsson and Lundholm, 2013). While this literature is focusing on how organizational leadership is communicatively enacted and co-constructed, the Luhmannian perspective also draws attention to the complex interrelation between the realm of communication and the individual human beings. Thus, rather than just examining how leadership materializes in communication, taking Luhmann seriously invites us to examine also where and how this very communication opens itself up to irritations from individual human beings and how the respective irritations are then, in turn, processed in communication. In this way, the focus is placed on the way in which the communication makes use of human being in constructing leadership.

Going beyond an examination of human agency per se, the Luhmannian approach also invites examinations of how human agency is referred to and thus constructed in the communication process itself. As we outlined before, decisions tend to be explicitly attributed to leaders or decision makers, as if the realized communications were under their control. In other words, the organization treats decisions as if they were the product of a decision maker rather than the product of the communication system itself. For organization communication scholars this offers interesting new lines of inquiry. One concerns the different functions that such fictions might serve. Luhmann himself already highlighted that attributing communications to human beings makes it easier to identify and communicate about the communications (Luhmann, 1995) and it also helps disguising the paradox of decision communications (Luhmann, 2018). In addition to that, one can think of a lot of other potential functions. For example, it might help redirecting responsibility for organizational failures 
away from the organization itself to the fictional decision makers. This, in a second step, also offers the opportunity to be seen to resolve the source of the problem by sacking the respective people, i.e. by withdrawing their rights to speak.

Another potential line of inquiry concerns the mechanisms of creating and sustaining the fiction of the decision maker. In this respect it might be particularly interesting to explore instances in which such fictions are contested. For example, often we find explicit attempts at countering attempted attributions of decision communications by redirecting attention back to the network of decisions - "I just followed the procedures." For example, in our own work (Cooren, 2010) we showed how Adolf Eichmann in his trial tried to counter the attribution of decisions to him as a person by arguing that he just executed what had already been decided before.

The acknowledgement of the communicative constitution of human agency also has important methodological consequences. If we accept that the meaning realized in the communicative process is independent from what people meant to say, researchers can concentrate on capturing the realized communications and do not have to be concerned with human beings' intentions. What matters are the communicatively realized meanings, not what is going on in people's head. In other words, the doings of human beings only matter as far as they function as decision premises for future decisions, that is, only if they enter the communication network as information feeding utterances feeding understanding. To a certain extent, our acts and their consequences speak for themselves, as determined by ensuing communications, and this is what the Luhmannian approach acknowledges by insisting on their communicative dimension. 


\section{HOW THE EXISTING RESEARCH ON ORGANIZATIONAL COMMUNICATION CAN INSPIRE LUHMANN'S THEORY}

Luhmann's work has not only the potential to inspire organizational communication scholars but also vice versa. In the following we will highlight three areas of such inspiration.

\section{Interpenetration as a logic of reciprocal appropriation}

As we explained above, Luhmann characterizes the relation between organizations and human beings as interpenetration; that is, organizations mobilize the complexity of the human beings as if it were their own. This form of appropriation is essential to be able to talk about autopoiesis, i.e., self-production, as an organization produces itself through appropriating what others end up doing and saying in its name or for it, whether intentionally or not (Bencherki and Cooren, 2011). This interpenetration logic allows Luhmann to talk about organizations as doing this or that, even if he does not really elaborate on how this is possible. In this regard, Luhmann's approach could be enriched with insights from the existing organizational communication literature, which might explain how this interpenetration is made possible (Cooren, 2010; McPhee and Zaug, 2000; Taylor and Van Every, 2000). If organizations can communicate, it is because agents are deemed as authorized to communicate on its behalf, an authority/authoring that is, of course, based on decisions about who can speak in its name (Benoit Barné and Cooren, 2009; Taylor and Van Every, 2014).

This point insists on what allows organizations to be positioned as actors making a difference in the world in which they evolve. It also insists on the key role communications play in this attribution (see especially Bencherki and Bourgoin, in press). In order to act and speak, an organization has, by definition, to rely on voices (the ones of CEOs, spokespersons, salespersons etc.) that position themselves or are positioned as speaking on its behalf, making it present, for another next first time, in various situations (Cooren, 2015). This means that appropriation is always relative and reciprocal. Relative because organizational appropriation 
is always partial, that is, organizations can never completely own other systems' actions; reciprocal because voices have their organizations as much as organizations have them.

This means that these voices also mobilize the complexity of their respective organizations as if it were their own, hence the effect of authority that are so crucial in organizational settings (Cooren, 2015; Taylor and Van Every, 2000). Appropriation is therefore a two-way relationship, which means that the phenomenon of autopoiesis always has to be analyzed in both directions: from the organization to the systems it appropriates, but also from these systems to the organization they also appropriate. We believe that it is through this logic of interpenetration that the becoming of organizations can and should be studied. This also explains why communications appear so central in this endeavor as it is, by excellence, where this interpenetration takes place (Bencherki and Bourgoin, in press). Thus, as we are arguing here, existing works on organizational communication can enrich our understanding of the interpenetration between organization and human beings that Luhmann described.

\section{Heteropoiesis and the hybrid character of agency}

Another key point, related to the previous one, concerns the question of autopoiesis or self-production, which, as we described above, is at the core of Luhmann's systems theory. Although Luhmann highlights the autopoietic nature of organizations, he also notes that this identification results from the way the phenomenon is observed. For instance, if top managers, who communicate in the name of their organization, ratify a strategic plan, the organization reproduces itself with this specific document (hence the autopoietic dimension of this move). However, we could point out that this self-organization also depends on a sort of alter- or hetero-poiesis, which other communicative perspectives allow us to examine (e.g., Cooren, 2010). 
By ratifying this strategic plan, the organization precisely produces a text that now has the capacity to tell or remind the organization itself (through, for instance, its top managers) what should be done in the future with regard to its strategy. This phenomenon not only highlights the hybrid character of agency, to the extent that it shows that not only humans, but also texts and other devices communicate for the organization (Cooren, 2004; Cooren and Bencherki, 2010; Putnam and Cooren, 2004, Vásquez, Bencherki, Cooren and Sergi, 2018), but it also shows that autopoiesis is always relative, depending on the point of reference one decides to choose and focus on.

Although the relative character of autopoiesis was implicitly acknowledged by Luhmann, especially through the concept of interpenetration mentioned above, we believe that its implications in terms of heteropoiesis were never fully examined. Seen from the organization's perspective, there is indeed self-production as the strategic plan has been created for that very purpose and is appropriated by the organization. However, seen from the top managers' or even the strategic plan's perspectives, it is their own contributions that organize, at least partly, the organization regarding its strategic features. For Luhmann, the strategic plan and the top managers who ratified it function merely as an irritation that is appropriated by the network of communication. Yet, we can also highlight the specific contributions of these irritations, which cannot be reduced to their appropriations.

Luhmann's characterization of organizations as autopoietic appears to position them as autonomous even though autopoiesis has, by definition, to rely on heteropoiesis, which is left as a black box (see also Schoeneborn, 2011, on the limitations of Luhmann's approach in addressing human and nonhuman agency). To use another example, when a company makes the rounds of potential customers, it relies on specific resources that will possibly make it autonomous (a salesperson, a cellular phone, a company car, a computer, samples, brochures, etc.) but this autonomy is, of course, relative, as it precisely relies on the salespersons, 
technologies and texts it mobilizes to autonomously do things. In other words, its own autonomy, relies, by definition, on a certain heteronomy, as it is still at the mercy of what its salespersons and all the things they will mobilize will do or not do for it.

Appropriation, as we see, is a key aspect of autopoiesis and autonomy, but appropriation cannot be absolute precisely because it remains to some extent always improper, heteronomous, as the human and nonhuman agents that are mobilized to assure self-production have their own autonomy, that is, they are themselves governed by their own laws (Cooren, 2010). This puts Luhmann's point in perspective, as it shows that autopoiesis also depends on forms of alter- or hetero-poiesis. If, as Luhmann reminds us, the identification of autopoiesis depends on how it is observed and analysed, it means, by definition, that this phenomenon is relative and always depends on how the activities of its elements are appropriated by the organization itself (Bencherki and Cooren, 2011; Bencherki and Snapp, 2016)

\section{Organization and organs outside formal organizations}

With his conceptualization of organizations as recursive network of decisions, Luhmann focused on what is usually referred to as "formal organizations." However, some organizational communication scholars, echoing Karl Weick's (1979) notion of “organizing,” have propagated a wider notion of organization beyond formal organizations (Taylor and Van Every, 2000, 2011, 2014), especially through the concept of organizationality (Dobusch and Schoeneborn, 2015; Schoeneborn, Kuhn and Kärreman, 2019). In our own work (Cooren and Fairhurst, 2009: 121), we have tried to illustrate this with the example of a group of friends who decide to help each other move:

For example, a group of individuals can organize themselves to accomplish a common objective (for example, moving) and develop some patterns of interaction, but this does not necessarily mean that this group constitutes a formal organization (for 
example, a moving company). They could just be a bunch of friends trying to help one of them to move.

In a step to widen Luhmann's organization theory to such organizational phenomena beyond formal organizations, we could introduce the concept of organs as we suggested elsewhere (Cooren, 2015, Cooren and Matte, in press). Organs can be understood etymologically as instruments or means designed for specific purpose. ${ }^{1}$ Whether we are talking about a simple to-do list we decide to write and then follow during the day, a software that automatically dispatches the closest ambulance for an emergency, or a strategic plan that detail various courses of action that a company ought to take in the future, we are dealing with organs to the extent that they actively contribute to the organ-izing of activities, that is, they actively structure various courses of action in order to fulfill specific objectives (Cooren and Matte, in press).

While we agree with Luhmann that decisions are key aspects of organizations, we believe that Luhmann hasn't recognized the important role that organs play in their constitution. These organs certainly have to be decided upon and Luhmann importantly remind us about that, but these decisions precisely lead to the creation of organs and it is these organs that, by definition, structure and organize systems while being part of them (hence, their autopoietic dimension). For instance, as soon as a group collectively decides about a specific course of action, they are getting organ-ized because they found a way not only to speak with one voice (they created an organ of phonation, so to speak), but also to divide labour (which amounts to creating various intermediaries or means by which collective action will take place). Decisions are therefore crucial for organizing, but the product of these decisions are also crucial, i.e., organs.

\footnotetext{
${ }^{1}$ While the terminology of organ could be accused of biologizing the reflection on organization and organizing, one could retort that biology actually appropriated this term, which initially meant instrument or means.
} 
Current communicative perspectives thus invite us to extend Luhmann's treatment of organizations to organizing more generally. Echoing Ahrne and Brunsson's (2011) idea of partial organization and Dobusch and Schoeneborn's (2015) notion of organizationality, we can speak of organization outside formal organizations whenever key aspects are decided upon - even though not everything is necessarily decided (see also Ahrne, Brunnson and Seidl, 2017). This shows that Luhmann's theory can also apply to organizing, and not only organizations. Organizing indeed implies deciding upon the creation of organs that will organize a group of people (or even just oneself). Since organs are also systems, it also means that they constitute sources of heteropoiesis whose effects can also be studied for their own sake.

\section{CONCLUSION}

In this essay we have tried to raise the awareness of organization and management scholars for the importance of Niklas Luhmann's communication approach to organizations, which has hitherto been treated only superficially and sporadically in organization studies internationally. We have argued that Luhmann's approach offers exciting new insights into the ways in which communication shapes organizations and thereby opens up new avenues particularly to organization communication scholarship. We have tried to demonstrate that adopting a Luhmannian approach (1) puts decisions back into organizational communication research, (2) invites us to explore how communications as events without duration produce organizational continuity, (3) urges us to examine how communications establish organizational boundaries and (4) directs our attention to the ways in which agency is communicatively established. We argued in turn that the Luhmannian approach can also be enriched with insights from other organizational communication research regarding questions related to (1) inter-penetration as a logic of reciprocal appropriation, (2) the heteropoietic and hybrid dimension of autopoiesis and (3) organization and organs outside formal organizations. 
This discussion about mutual inspirations between theoretical perspectives raises the more general question about the relation between various approaches to organizational communication, which are based on very different theoretical traditions and associated assumptions (Schoeneborn 2011; Schoeneborn et al., 2014). As a consequence, there is no point in attempting to integrate them. Apart from problems of incommensurability, attempts at integration would also reduce the potential richness of insights resulting from the pluralism of theories - analogously to the pluralism of theories in organization studies in general (Scherer, 1998). However, as we have tried to illustrate in this Review Essay there is a potential for cross-fertilization between these different theories. We showed how key insights from a Luhmannian approach might invite and inspire scholars to address aspects of the communicative constitution of organizations that they might otherwise miss - and vice versa. Hence, with this review essay we also hope to encourage more fruitful dialogue across the different theoretical strands (for an example of such a dialogue, see Schoeneborn et al, 2014).

\section{References}

Ahrne, G., \& Brunsson, N. (2011). Organization outside organizations: the significance of partial organization. Organization, 18(1), 83-104.

Ahrne, G., Brunsson, N., \& Seidl, D. (2016). Resurrecting organization by going beyond organizations. European Management Journal, 34, 93-101.

Albu, O. B., \& Etter, M. (2016). Hypertextuality and Social Media: A Study of the Constitutive and Paradoxical Implications of Organizational Twitter Use. Management Communication Quarterly, 30(1), 5-31

Ashcraft, K. L., Kuhn, T., \& Cooren, F. (2009). Constitutional Amendments: "Materializing" Organizational Communication. The Academy of Management Annals, 3(1), 1-64.

Aten, K., \& Thomas, G. F. (2016). Crowdsourcing strategizing: Communication technology affordances and the communicative constitution of organizational strategy. International Journal of Business Communication, 53(2), 148-180.

Bateson, G. (1979). Mind and nature: A necessary unity. New York, E. P. Dutton:.

Becker, K.-H. \& Seidl, D. (2007). Different kinds of openings of Luhmann's Systems Theory: A reply to la Cour et al.. Organization, 14(6): 939-944.

Bencherki, N. (2016). How things make things do things with words, or how to pay attention to what things have to say. Communication Research and Practice, 2(3), 272-289.

Bencherki, N., \& Bourgoin, A. (in press). Property and Organization Studies. Organization Studies, 1-17. https://doi.org/10.1177/0170840617745922

Bencherki, N., \& Cooren, F. (2011). Having to be: The possessive constitution of organization. Human Relations, 64(12), 1579-1607. 
Bencherki, N., \& Snack, J. P. (2016). Contributorship and partial inclusion: A communicative perspective. Management Communication Quarterly, 30(3), 279-304.

Benoit Barné, C., \& Cooren, F. (2009). The accomplishment of authority through presentification: How authority is distributed among and negotiated by organizational members. Management Communication Quarterly, 23(1), 5-31.

Boivin, G., Brummans, B. H. J. M., \& Barker, J. R. (2017). The institutionalization of CCO scholarship: Trends from 2000 to 2015. Management Communication Quarterly, 31(3), 331355.

Browning, L. D., Greene, R. W., Sitkin, S. B., Sutcliffe, K. M., \& Obstfled, D. (2009). Constitutive complexity: Military entrepreneurs and the synthetic character of communication flows. In L. L. Putnam \& A. M. Nicotera (Eds.), Building theories of organization: The constitutive role of communication (pp. 89-116). Oxford: Routledge.

Brummans, B. H. J. M. (2007). Death by Document: Tracing the Agency of a Text. Qualitative Inquiry, 13(5), 711-727.

Brummans, B. H. J. M. (Ed.) (2018). The agency of organizing: Perspectives and case studies. New York: Routledge.

Brummans, B. H. J. M. (2007). Death by document: Tracing the agency of a text. Qualitative Inquiry, 13(5), 711-727.

Brummans, B. H. J. M., Cooren, F., Robichaud, D., \& Taylor, J. R. (2014). Approaches in research on the communicative constitution of organizations. In L. L. Putnam \& D. K. Mumby (Eds.), Sage handbook of organizational communication (pp. 173-194). Thousand Oaks, CA: Sage.

Bruscella, J. S., \& Bisel, R. S. (2018). Four Flows theory and materiality: ISIL's use of material resources in its communicative constitution. Communication Monographs, 85(3), 331-356.

Bülher, K. (1990/1934). Theory of language: The representational function of language. Amsterdam: John Benjamins.

Cabantous, L., Gond, J.-P., \& Wright, A. (2018). The performativity of strategy: Taking stock and moving ahead. Long Range Planning, 51(3), 407-416.

Castelló, I., Morsing, M., \& Schultz, F. (2013). Communicative dynamics and the polyphony of corporate social responsibility in the network society. Journal of Business Ethics, 118(4), 683-694.

Christensen, L. T., Morsing, M., \& Thyssen, O. (2011). The polyphony of corporate social responsibility: Deconstructing accountability and transparency in the context of identity and hypocrisy. In G. Cheney, S. May, \& D. Munshi (Eds.), Handbook of communication ethics (pp. 457-474). New York: Routledge.

Christensen, L. T., Morsing M., \& Thyssen, O. (2013). CSR as aspirational talk. Organization 20(3), 372-393.

Clifton, J. (2015). Leaders as ventriloquists: Leader identity and influencing the communicative construction of the organization. Leadership, 13, 301-319.

Clifton J. (2017) Taking the (heroic) leader out of leadership: The in situ practice of distributed leadership in decision-making talk. In Ilie C., Schnurr S. (Eds) Challenging leadership stereotypes through discourse (pp. 45-68). Singapore: Springer.

Cooren, F. (2000). The organizing property of communication. Amsterdam / Philadelphia: John Benjamins.

Cooren, F. (2004). Textual agency: How texts do things in organizational settings. Organization, 11(3), 373-393.

Cooren, F. (2006). The organizational world as a plenum of agencies. In F. Cooren, J. R. Taylor, \& E. J. Van Every (Eds.), Communication as organizing: Empirical and theoretical explorations in the dynamic of text and conversation (pp. 81-100). Mahwah, NJ: Lawrence Erlbaum.

Cooren, F. (2008). Between semiotics and pragmatics: Opening language studies to textual agency. Journal of Pragmatics, 40, 1-16. 
Cooren, F. (2009). The haunting question of textual agency: Derrida and Garfinkel on iterability and eventfulness. Research on Language and Social Interaction, 42(1), 42-67.

Cooren, F. (2010). Action and Agency in Dialogue: Passion, incarnation, and ventriloquism. Amsterdam/Philadelphia: John Benjamins.

Cooren, F. (2015). Organizational discourse: Communication and constitution. London: Polity.

Cooren, F. (in press). A communicative constitutive perspective on corporate social responsibility: Ventriloquism, undecidability, and surprisability. Business \& Society.

Cooren, F., \& Bencherki, N. (2010). How things do things with words: Ventriloquism, passion and technology. Encyclopaideia, XIV(28), 35-62.

Cooren, F., Bencherki, N., Chaput, M., \& Vasquez, C. (2015). The communicative constitution of strategy-making: Exploring fleeting moments of strategy. In D. Golsorkhi, L. Rouleau, D. Seidl, \& E. Vaara (Eds.), The Cambridge Handbook of Strategy as Practice (2nd ed., pp. 365-388). Cambridge, UK: Cambridge University Press.

Cooren, F., Brummans, B. H. J. M., \& Charrieras, D. (2008). The coproduction of organizational presence: A study of Médecins Sans Frontières in action. Human Relations, 61(10), 13391370.

Cooren, F., \& Fairhurst, G. T. (2009). Dislocation and stabilization: How to scale up from interactions to organization. In L. L. Putnam \& A. M. Nicotera (Eds.), The communicative constitution of organization: Centering organizational communication (pp. 117-152). Mahwah, NJ: Lawrence Erlbaum Associates.

Cooren, F., Kuhn, T., Cornelissen, J. P., \& Clark, T. (2011). Communication, organizing and organization: An overview and introduction to the special issue. Organization Studies, 32, 1149-1170.

Cooren, F., \& Matte, F. (forthcoming). Between media studies and organizational communication: Organizing as the creation of organs. In J. Swartz, \& J. Wasko (eds.), Media: Experience, Exploration, Emergence. Bristol, UK: Intellect Books

Czarniawska, B. (2017). Bruno Latour and Niklas Luhmann as organization theorists. European Management Journal, 35, 145- 150

Dobusch, L., \& Schoeneborn, D. (2015). Fluidity, identity, and organizationality: The communicative constitution of Anonymous. Journal of Management Studies, 52(8), 1005-1035.

Fairhurst, G. T., \& Cooren, F. (2018). Organizational discourse analysis. In C. Cassell, Ann L Cunliffe, \& G. Grandy (Eds.), The Sage handbook of qualitative business and management methods (pp. 82-101). London: Sage.

Fauré, B., Cooren, F., \& Matte, F. (2019). To speak or not to speak the language of numbers: accounting as ventriloquism, Accounting, Auditing \& Accountability Journal, 32(1), 337361.

Frandsen, S., Kuhn, T., \& Wolff Lundholt, M. (Eds.). (2016). Counter-narratives and organization. New York: Routledge.

Giddens, A. (1979). Central Problems in Social Theory: Action, Structure and Contradiction in Social Analysis. London: McMillan.

Giddens, A. (1984). The Constitution of Society. Cambridge, UK: Polity Press.

Helge Becker, K., \& Haunschild, A. (2003). The impact of boundaryless careers on organizational decision making: an analysis from the perspective of Luhmann's theory of social systems. International Journal of Human Resource Management, 14(5), 713-727.

Hernes, T., \& Bakken, T. (2003). Implications of self-reference: Niklas Luhmann's autopoiesis and organization theory. Organization Studies, 24(9), 1511-1535.

Heritage, J. (1984). Garfinkel and Ethnomethodology. Cambridge, UK: Polity Press.

Holm, F., \& Fairhurst, G. T. (2018). Configuring shared and hierarchical leadership through authoring. Human Relations, 71(5), 692-721. 
Jahn, J. L. S. (2016). Adapting safety rules in a high reliability context: How wildland firefighting workgroups ventriloquize safety rules to understand hazards. Management Communication Quarterly, 30(3), 362-389.

Joerges, B., \& Czarniawska, B. (1998). The question of technology, or how organizations inscribe the world. Organization Studies, 19(3), 363-385.

Kast, F. E., \& Rosenzweig, J. E. (1972). General systems theory: Applications for organization and management. Academy of Management Journal, 15(4), 447-465.

Kieser, A., \& Leiner, L. (2009). Why the rigour-relevance gap in management research is unbridgeable. Journal of Management Studies, 46(3), 516-533.

Knudsen, M. (2005)Displacing the Paradox of Decision Making. In:D. Seidl and K-H. Becker (eds.) Niklas Luhmann and Organization Studies. Copenhagen: Liber: 107-126.

Koschmann, M. A., Kuhn, T. R., \& Pfarrer, M. D. (2012). A communicative framework of value in cross-sector partnerships. Academy of Management Review, 37(3), 332-354.

Koschmann, M. A., \& McDonald, J. (2015). Organizational Rituals, Communication, and the Question of Agency. Management Communication Quarterly, 29(2), 229-256.

Kuhn, T. (2008). A communicative theory of the firm: Developing an alternative perspective on intraorganizational power and stakeholder relationships. Organization Studies, 29(8-9), 12271254.

Kuhn, T., Ashcraft, K. L., \& Cooren, F. (2017). The work of communication: Relational perspectives on working and organizing in contemporary capitalism. New York: Routledge.

Kuhn, T., \& Burk, N. R. (2014). Spatial design as sociomaterial practice: A (dis)organizing perspective on communicative constitution. In F. Cooren, E. Vaara, A. Langley, \& H. Tsoukas (Eds.), Language and Communication at Work: Discourse, Narrativity, and Organizing (pp. 147-172). Oxford, UK: Oxford University Press.

Langenmayr, F. (2016). Organisational Memory as a Function: The Construction of Past, Present and Future in Organisations. Berlin: Springer.

Langley, A., Smallman, C., Tsoukas, H. and Van de Ven, A. (2013) Process studies of change in organization and management: unveiling temporality, activity, and flow. Academy of Management Review 56(1): 1-13.

Langley, A. and Tsoukas, H. (2016) The SAGE Handbook of Process Organization Studies. Thousand Oaks: Sage.

Larsson, M. (2017). Leadership in interaction. In J. Storey, J. Hartley, J.-L. Denis, P. 't Hart, \& D. Ulrich (Eds.), The Routledge companion to leadership (pp. 173-193). New York: Routledge.

Larsson, M., \& Lundholm, S. E. (2013). Talking work in a bank: A study of organizing properties of leadership in work interactions. Human Relations, 66(8), 1101-1129.

Lawrence, P., \& Lorsch, J. (1967). Organizations and environments. Homewood, IL: Irwin.

Lorino, P. (2014). From speech acts to act speeches: Collective activity, a discursive process speaking the language of habits. In F. Cooren, E. Vaara, A. Langley, \& H. Tsoukas (Eds.), Language and communication at work: Discourse, narrativity, and organizing (pp. 95-124). Oxford, UK: Oxford University Press.

Luhmann, N. (1987) Archimedes und wir. Interviews, eds D. Baecker and G. Stanitzeck. Berlin: Merve

Luhmann, N. (1988) Organisation". In: W. Küpper and G. Ortmann (eds.) Mikropolitik: Rationalitat, Macht und Spiele in Organisationen. Opladen: Westdeutscher Verlag [Translated:

"Organization", in T. Bakken and T. Hernes (2003) (eds.), Autopoietic Organization Theory: Drawing on Niklas Luhmann's Social Systems Perspective (Copenhagen: Copenhagen

Business School Press), 31-52]

Luhmann, N. (1995). Social Systems. Stanford: Stanford University Press.

Luhmann, N. (2002) "How Can the Mind Participate in Communication?", in N. Luhmann, Theories of Distinction: Redescribing the Descriptions of Modernity (Stanford, CA: Stanford University Press), 169-186 
Luhmann, N. (2005). 'The paradox of decision making'. In: Seidl, David/Becker, Kai Helge (Eds.). Niklas Luhmann and Organization Studies. Liber \& Copenhagen Business School Press. 85106.

Luhmann, N. (2003) Organization. In: Tor Hernes / Tore Bakken (eds.) Autopoietic Organization Theory. Drawing on Niklas Luhmann's Social Systems Perspective. Copenhagen:

Copenhagen Business School Press, pp. 31-52.

Luhmann, N. (2012a) Introduction to Systems Theory. Polity Press.

Luhmann, N. (2012b) Theory of Society. Vol. II. Stanford. Stanford University Press.

Luhmann, N. (2013) Theory of Society. Vol. II. Stanford. Stanford University Press.

Luhmann, N. (2018). Organization and decision. Cambridge, UK: Cambridge University Press.

March, J. G. (1994). A primer on decision making. How decisions happen. New York. Free Press.

March, J. G., \& Simon, H. A. (1958). Organizations. New York: Wiley.

Martine, T., Cooren, F., \& Bartels, G. (in press). Evaluating creativity through the degrees of solidity of its assessment: A relational approach. Journal of Creative Behavior.

Maturana, H. R., and Varela, F. J.. (1992) The tree of knowledge: The biological roots of human understanding. Revised edition. New Science Library/Shambhala Publications.

Mayo, E. (1947). The social problems of an industrial civilization. London: Routledge \& Kegan Paul.

McPhee, R. D. (2004). Text, agency, and organization in the light of structuration theory. Organization, 11(3), 355-371.

McPhee, R. D., \& Iverson, J. (2009). The communicative constitution of organizations: A framework for explanation. In L. L. Putnam \& A. M. Nicotera (Eds.), Building theories of organization: The constitutive role of communication (pp. 21-47). New York/London: Routledge.

McPhee, R. D., \& Zaug, P. (2000). The communicative constitution of organizations: A framework for explanation. The Electronic Journal of Communication / La revue électronique de communication, 10(1/2), 1-16.

Pälli, P. (2018). Ascribing materiality and agency to strategy in interaction: A language-based approach to the material agency of strategy. Long Range Planning, 51(3), 436-450.

Putnam, L. L., \& Cooren, F. (2004). Alternative perspective on the role of text and agency in constituting organizations. Organization, 11(3), 323-333.

Putnam, L. L., \& Nicotera, A. M. (Eds.). (2009). Building theories of organization: The constitutive role of communication. New York: Routledge.

Robichaud, D., \& Cooren, F. (2013). Organization and organizing: Materiality, agency and discourse. New York: Routledge.

Robichaud, D., Giroux, H., \& Taylor, J. R. (2004). The meta-conversation: The recursive property of language as the key to organizing. Academy of Management Review, 29(4), 617-634.

Schegloff, E. A. (1991). Conversation Analysis and Socially Shared Cognition. In L. B. Resnick, J. L. Levine, \& S. D. Teasley (Eds.), Perspectives on Socially Shared Cognition (pp. 150-171). Washington, DC: American Psychological Association.

Scherer, A. G. (1998) Pluralism and incommensurability in strategic management and organization theory: A problem in search of a solution. Organization 5(2): 147-168.

Schnebel, E. 2000. Values in decision-making processes: Systematic structures of J. Habermas and N. Luhmann for the appreciation of responsibility in leadership. Journal of Business Ethics, 27: 79-88.

Schoeneborn, D. (2011) Organization as communication: A Luhmannian perspective. Management Communication Quarterly 25(4): 663-689.

Schoeneborn, D., \& Trittin, H. (2013). Transcending transmission: Towards a constitutive perspective on CSR communication. Corporate Communications: An International Journal, $18(2), 193-211$. 
Schoeneborn, D., Blaschke, S., Cooren, F., McPhee, R. D., Seidl, D., \& Taylor, J. R. (2014). The three schools of CCO thinking: Interactive dialogue and systematic comparison. Management Communication Quarterly, 28(2), 285-316.

Schoeneborn, D., Kuhn, T. R., \& Kärreman, D. (2019). The communicative constitution of organization, organizing, and organizationality. Organization Studies, 40(4), 475-496.

Schoeneborn, D., \& Vásquez, C. (2017). Communicative constitution of organizations. In C. R. Scott, L. Lewis, J. R. Barker, J. Keyton, T. Kuhn, \& P. K. Turner (Eds.), The International Encyclopedia of Organizational Communication (Vol. 1, pp. 367-386). Hoboken, NJ: Wiley

Seidl, D. \& Becker, K.H. (2006) Organisations as distinction generating and processing systems. Niklas Luhmann's contribution to Organisation Studies. Organization, 13 (1): 9-35.

Seidl, D. (2005) "The Basic Concepts of Luhmann's theory of social systems". In David Seidl/ Kai Becker (eds.) Niklas Luhmann and Organization Studies. Copenhagen: Copenhagen Business School Press, pp. 21-53.

Shannon, C. E., \& Weaver, W. (1949). The mathematical theory of communication. Cambridge, MA: MIT Press.

Smith, S., \& Ward, V. (2015). The role of boundary maintenance and blurring in a UK collaborative research project: How researchers and health service managers made sense of new ways of working. Social Science \& Medicine, 130, 225-233.

Spee, A. P., \& Jarzabkowski, P. (2011). Strategic planning as communicative process. Organization Studies, 32(9), 1217-1245.

Taylor, F. W. (1911). The Principles of Scientific Management. New York: Harper \& Brothers.

Taylor, J. R. (1988). Une organisation n'est qu'un tissu de communications. Montréal: Cahiers de recherches en communication.

Taylor, J. R. (1993). Rethinking the Theory of Organizational Communication : How to Read an Organization. Norwood, NJ: Ablex.

Taylor, J. R., Cooren, F., Giroux, N., \& Robichaud, D. (1996). The communicational basis of organization: Between the conversation and the text. Communication Theory, 6(1), 1-39.

Taylor, J. R. \& Robichaud, D. (2011). Finding the organization in communication: Discourse as action and sensemaking. In D. Grant, L. L. Putnam \& C. Hardy (Eds.). Organizational discourse studies (3 volume set). SAGE Major works series. Los Angeles, CA: SAGE.

Taylor, J. R., \& Van Every, E. J. (2000). The emergent organization. Communication as site and surface. Mahwah, NJ: Lawrence Erlbaum Associates.

Taylor, J. R., \& Van Every, E. J. (2011). The situated organization: Case studies in the pragmatics of communication. New York: Routledge.

Taylor, J. R., \& Van Every, E. J. (2014). When organization fails: Why authority matters. New York: Routledge.

Thyssen, O. (2012). Introduction to Luhmann. Cybernetics \& Human Knowing, 19(4), 117-119.

Trittin, H. \& Schoeneborn, D. (2017). Diversity as polyphony: Reconceptualizing diversity management from a communication-centered perspective. Journal of Business Ethics, 144, 305322

Tsoukas, H., \& Chia, R. (2002). "On organizational becoming: Rethinking organizational change." Organization Science 13(5): 567-582.

Vaara, E., Sorsa, V., \& Pälli, P. (2010). On the force potential of strategy texts: A critical discourse analysis of a strategic plan and its power effects in a city organization. Organization, 17(6), 685-702.

Valentinov, V. (2012). The complexity-sustainability trade-offs in Niklas Luhmann's social systems theory. Systems Research and Behavioral Science, 31(1), 14-22.

Valentinov, V. (2013). Corporate social responsibility and sustainability: insights from Boulding and Luhmann. International Journal of Sustainable Development \& World Ecology, 20(4), 317324. 
van Lier, B. (2013). Luhmann meets Weick: Information interoperability and situational awareness. Emergence: Complexity and Organization, 15(1), 71-95.

Vaara, E., Sorsa, V., \& Pälli, P. (2010). On the force potential of strategy texts: A critical discourse analysis of a strategic plan and its power effects in a city organization. Organization, 17(6), 685-702.

Vásquez, C., Schoeneborn, D., \& Sergi, V. (2016). Summoning the spirits: Organizational texts and the (dis)ordering properties of communication. Human Relations, 69(3), 629-659.

Vásquez, C., Bencherki, N., Cooren, F., \& Sergi, V. (2018). From 'matters of concern' to 'matters of authority': Studying the performativity of strategy from a communicative constitution of organization (CCO) approach. Long Range Planning, 51, 417-435.

Weber, M. (1947). The Theory of Social and Economic Organization (tr. A. M. Henderson and T. Parsons), New York: Oxford University Press.

Weick, K. E. (1979). The Social Psychology of Organizing. New York: Random House.

Weick, K. E. (1995). Sensemaking in Organizations. Thousand Oaks: Sage.

Wilhoit, E. D., \& Kisselburgh, L. G. (2015). Collective action without organization: The material constitution of bike commuters as collective. Organization Studies, 36(5), 573-592. 